\title{
基于吲哚酸单元的那西肽生物合成途径中酶底物容忍度研究
}

\author{
范亚飞 ${ }^{a}$ 张 鄂 ${ }^{a}$ 郭 恒 ${ }^{b}$ 牟 柠 ${ }^{a}$ 陈单丹 $b$ \\ 王文贵 $a$ 王守锋*, $a$ 刘 文*,b,c \\ ( ${ }^{a}$ 济南大学化学化工学院 山东省氟化学化工材料重点实验室 济南 250022) \\ ( ${ }^{b}$ 中国科学院上海有机化学研究所 生命有机化学国家重点实验室 上海 200032) \\ ( ${ }^{c}$ 中国科学院上海有机化学研究所 湖州生物制造中心 浙江湖州 313000)
}

\begin{abstract}
摘要 那西肽(NOS)是硫肽类抗生素的典型代表，具有非常好的抗菌活性，但水溶性差以及生物利用度低等问题限制 了其临床上的应用. 由于其结构复杂, 采用化学全合成方式获得理化性质改善的类似物难以进行. 在前期那西肽生物 合成研究的基础上，以侧环 3-甲基-2-吲哚酸(MIA)类似物作为化学探针，通过探针分子与突变株共同发酵并结合发酵 产物的高分辨质谱数据, 探究了那西肽生物合成酶的底物容忍度. 研究结果表明, 那西肽生物合成酶对 $\mathrm{F}, \mathrm{Cl}, \mathrm{CH}_{3}$ 取代 的 MIA 类似物有一定的耐受能力, 对大位阻取代基 $\left(\mathrm{NO}_{2}, \mathrm{CF}_{3}, \mathrm{Ph}\right)$ 的 MIA 类似物不能耐受，同时 MIA 上取代基团的结 构大小和性质也影响了 NOS 生物合成途径中相关酶蛋白对其识别、转运和上载等步骤. 不仅探究了 NOS 生物合成途 径中相关酶蛋白的底物容忍度，有望通过生物合成途径工程获得 NOS 的类似物; 同时为采用酶的定向进化技术以改善 NOS 生物合成过程中限速步骤酶的底物容忍度，拓展利用 NOS 产生菌获得更多类似物提供了借鉴.
\end{abstract}

关键词 那西肽; 3-甲基-2-吲哚酸; 突变生物合成; 化学小分子探针; 酶底物容忍度

\section{Insights into the Substrate Tolerance of Enzymes Involved in the Nosiheptide Biosynthesis Pathway Based on Indolic Acid Moiety}

\author{
Fan, Yafei ${ }^{a} \quad$ Zhang, $\mathrm{E}^{a}$ \\ Guo, Heng ${ }^{b} \quad \mathrm{Mu}$ Ning $^{a}$ \\ Chen, Dandan ${ }^{b}$ \\ Wang, Wengui ${ }^{a}$ \\ Wang, Shoufeng*,a \\ Liu, Wen $*, b, c$ \\ ( ${ }^{a}$ Shandong Provincial Key Laboratory of Fluorine Chemistry and Chemical Materials, School of Chemistry and \\ Chemical Engineering, University of Jinan, Jinan 250022) \\ ( ${ }^{b}$ State Key Laboratory of Bioorganic and Natural Products Chemistry, Shanghai Institute of Organic Chemistry, \\ Chinese Academy of Sciences, Shanghai 200032) \\ ( ${ }^{c}$ Huzhou Center of Bio-Synthetic Innovation, Shanghai Institute of Organic Chemistry, Chinese Academy of \\ Sciences, Huzhou, Zhejiang 313000)
}

\begin{abstract}
As a typical representative of thiopeptide antibiotics, nosiheptide (NOS) possesses very good antibacterial activity. However, due to poor water solubility and low bioavailability, its clinical application is hampered. Due to its complex structure, it is difficult to obtain analogues with improved physical and chemical properties via total chemical synthesis. Based on the previous studies on the biosynthesis of nosiheptide, the side-ring 3-methyl-2-indoleic acid (MIA) analogues were used as chemical small molecule probes to explore the substrate tolerance of enzymes involved in NOS biosynthesis pathway in NOS-producing bacteria via the co-fermentation of probe molecules with mutant strain and the combination of high resolution mass spectrometry data of fermentation products. The results showed that enzymes involved in NOS biosynthesis pathway had
\end{abstract}

\footnotetext{
* Corresponding authors. E-mail: chm_wangsf@ujn.edu.cn; wliu@mail.sioc.ac.cn

Received June 28, 2020; revised August 6, 2020; published online September 8, 2020.

Dedicated to the 40th anniversary of Chinese Journal of Organic Chemistry.

Project supported by the National Natural Science Foundation of China (Nos. 31972850, 21750004, 21520102004), the Shandong Key Research Program (No. 2019GSF108223), the Chinese Academy of Sciences (Nos. QYZDJ-SSW-SLH037, XDB20020200), the Science and Technology Commission of Shanghai Municipality (No. 17JC1405100), the Youth Innovation Promotion Association of the Chinese Academy of Sciences (No. 2017303), the State Key Laboratory of Microbial Technology Open Projects Fund (No. M2020-05) and the K. C. Wong Education Foundation.

国家自然科学基金(Nos. 31972850, 21750004，21520102004)、山东省重点研发计划(No. 2019GSF108223)、中国科学院(Nos. QYZDJ-SSW-SLH037, XDB20020200)、上海市科委(No. 17JC1405100)、中国科学院青年创新促进会(No. 2017303)、微生物技术国家重点实验室开放课题基金(No. M2020-05) 和王宽诚教育基金会资助项目。
} 
a considerable tolerance to MIA analogues substituted by $\mathrm{F}, \mathrm{Cl}$ and $\mathrm{CH}_{3}$, however, MIA analogues substituted by large steric hindrance group, such as $\mathrm{NO}_{2}, \mathrm{CF}_{3}$ and $\mathrm{Ph}$, were not tolerated. The position, the size and the property of the substituted groups of MIA also affected the steps of identification, transport and upload of the related enzymes involved in NOS biosynthesis. The present study not only explored the substrate tolerance of enzymes involved in NOS biosynthesis pathway, but also was expected to obtain NOS analogues via biosynthetic pathway engineering. What's more, it provides valuable information for using directed evolution technology to improve the substrate tolerance of enzymes in the rate-limiting steps of NOS biosynthesis and to expand the use of NOS-producing bacteria to obtain more analogues.

Keywords nosiheptide; 3-methyl-2-indolic acid; mutational biosynthesis; chemical small molecule probe; substrate tolerance of enzymes

\section{Introduction}

All the time, natural products play a highly significant role in the drug discovery and development process and still held out the best options for finding novel agents/ active templates, which when worked on in conjunction with organic chemists and biologists. ${ }^{[1]}$ Thiopeptide antibiotics are a class of ribosomally synthesized and posttranslationally modified peptide (RiPP) natural products, displaying nanomolar potency toward various drugresistant strains of Gram-positive pathogens ${ }^{[2]}$ Nosiheptide (NOS), as a typical representative of thiopeptide antibiotics, is one of the oldest known thiopeptide antibiotics, which is firstly isolated from Streptomyces actuosus 40037 (NRRL 2954), and later isolated from Streptomyces antibioticus $8446-\mathrm{CCl}^{[3]}$ and strain CNT-373. ${ }^{[4]}$ NOS has been used as a feed additive to promote growth in pigs and poultry. NOS is very active in vitro against Gram-positive bacteria (MIC $0.9 \mathrm{ng} / \mathrm{mL}$ against Staphylococcus aureus ATCC 6538P) but inactive in vivo in experimentally infected mice. ${ }^{[3]}$ Mechanically, NOS exerts its antibacterial effect by binding within a cleft located between the L11 protein and 23S rRNA of the 50S large ribosomal subunit, thereby perturbing translation factor binding and subsequent bacterial protein synthesis. ${ }^{[5]}$ The mode of action is unique and distinct from those of current chemotherapeutics targeting the bacterial ribosome. ${ }^{[6]}$ The clinical application of NOS, however, is largely hindered due to its poor water solubility and low bioavailability.

Structurally, NOS is composed of a macrocycle with a fused side-ring structure. The core macrocycle contains a central pyridine ring, multiple thiazoles, dehydrated serine and threonine amino acids. The side-ring structure is formed by connecting the side chains of Glu6 and Cys8 on the core macrocycle via ester and thioester bonds, respectively, with a 3-methyl-4-hydroxymethyl-2-indolic acid bridge. NOS has been chemically synthesized in $2016,{ }^{[7]}$ however, using chemical synthesis to improve its pharmacological properties have not been reported, most likely is subjected to its highly complex chemical structure. The biosynthetic pathway for NOS formation, which relies on the extensive modification of a ribosomally synthesized precursor peptide, offers the potential for relatively facile generation of analogues via biosynthetic methods. ${ }^{[8]}$ The biosynthetic gene cluster of NOS was identified and contains 16 genes (Figure 1A), designated nosA-nos $\mathrm{P}^{[9]}$ The formation of NOS starts from NosM, a ribosomally synthesized precursor peptide of 50 amino acids (aa). As shown in Figure 1B, the first 37 aa of the precursor peptide, termed the leader peptide, primarily provide recognition for some of the downstream enzymes, while the remaining 13 aa, called the core peptide, are posttranslationally modified and incorporated into the final product. The biosynthesis of core macrocycle is initiated by thiazole formation, catalyzed by NosF, NosG and NosH. However, Cys8 is left intact during thiazole formation and is immediately acylated with 3-methyl2-indolic acid (MIA) by NosI, NosJ and NosK..$^{[10,13-14]}$ MIA is derived from $L$-Trp via the action of NosL. ${ }^{[1-12]}$ And then NosN transfered a $\mathrm{C}_{1}$ unit from SAM to C(4) of MIA with concomitant formation of a bond between the carboxylate of Glu6 of the core peptide and the nascent $C_{1}$ unit. ${ }^{[15-17]}$ Dehydroalanine (Dha) and dehydrobutyrine (Dhb) are likely to be formed via the hydroxyl groups on the side chains of Ser1, Ser10, Ser12, Ser13, and Thr3 activization and dehydration, catalyzed by NosD and NosE. ${ }^{[18]}$ The Dha derived from Ser1 and Ser10 are then cyclized by $\mathrm{Nos} O$ via a [4+2] azacycloaddition to remove the leader peptide and form the core pyridine motif..$^{[19-20]}$ NosA, NosB and NosC are tailoring enzymes in the later stages of the maturation of NOS (Scheme 1). ${ }^{[1-22]}$

In our previous work, by feeding 5-F-Trp into wild type NOS strain, we obtained 5'-F-NOS whose antibacterial activity is improved, suggesting that the side-ring structure of NOS is important for its antibiotic properties. ${ }^{[12]}$ However, due to the competition of $L$-Trp in the native biosynthetic machinery, a mixture of NOS and 5'-F-NOS were

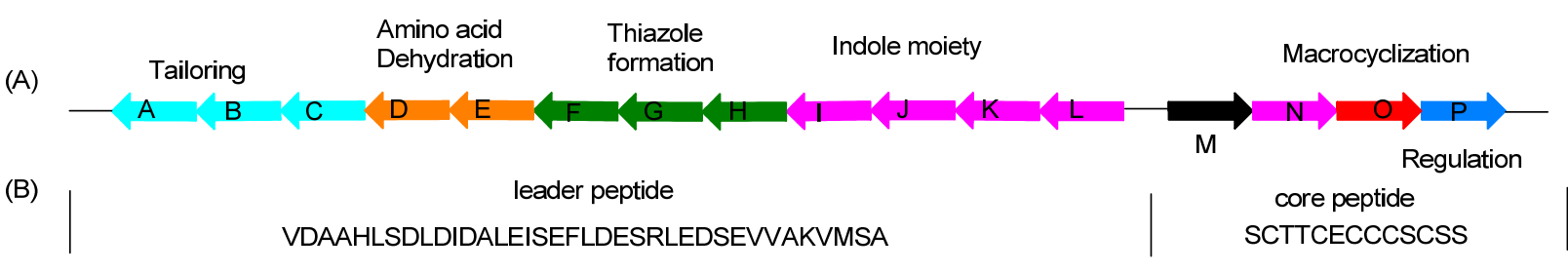

Figure 1 (A) Biosynthetic gene cluster of NOS and (B) amino acid sequence of NosM 

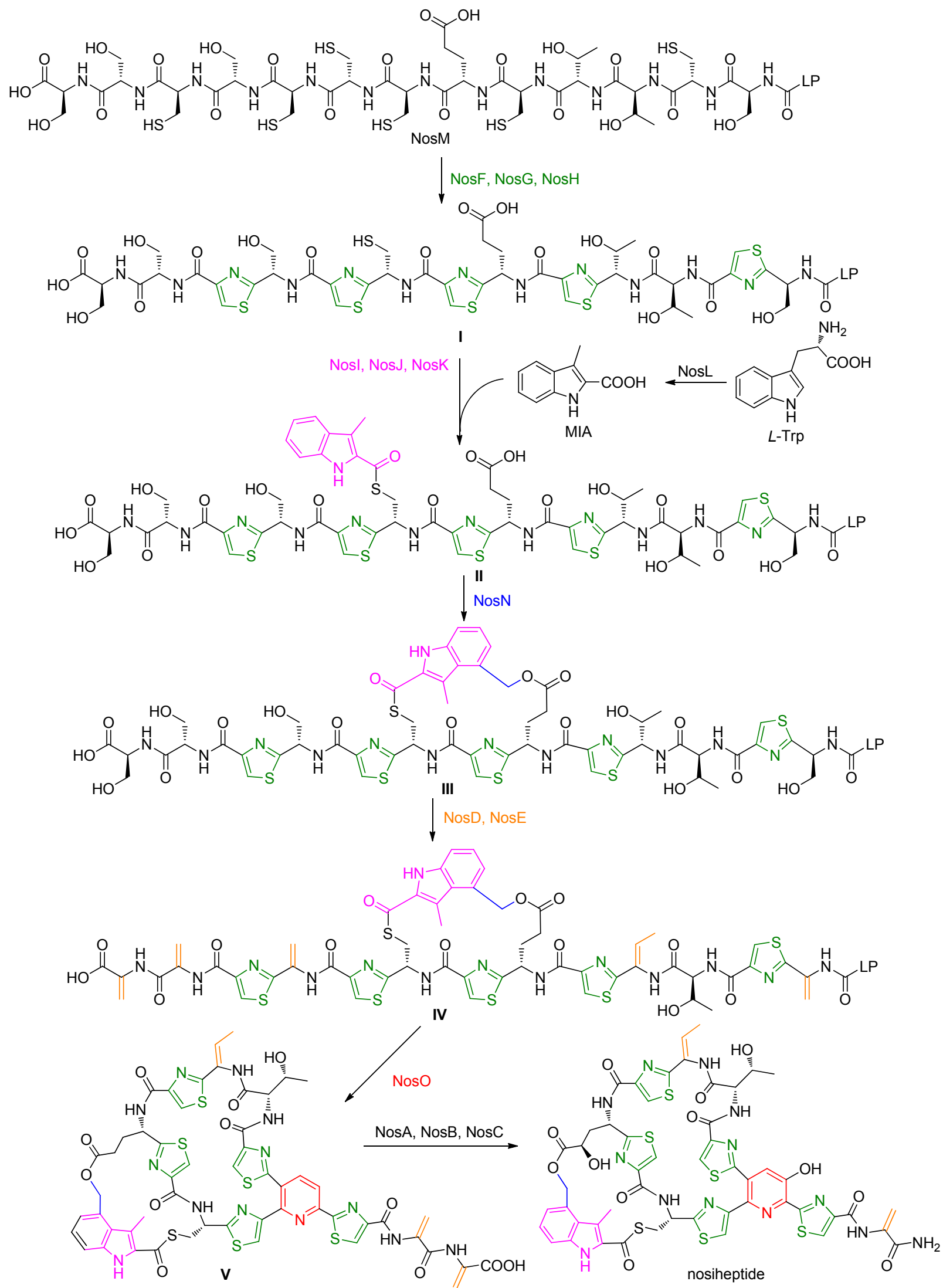

Scheme 1 proposed NOS biosynthetic pathway

co-produced, leading to complex compound purification burden. Based on precursor-directed biosynthesis, muta- tional biosynthesis can utilize mutant strains deficient in a key aspect of the biosynthetic pathway and directionally 
produce natural product analogues via supplementation of particular precursors. ${ }^{[23]}$ Recently, we established an efficient mutational biosynthesis strategy for the structural expansion of the side-ring system of NOS. By feeding 6-F-MIA into a nosL-deficient mutant strain, $\Delta$ nosL, 6'-F-NOS with significantly improved activities against drug-resistant pathogens were successfully obtained. What's more, an unexpected product, named as 6'-F-NOSint, with an open side ring and a bis-dehydroalanine (Dha) tail, was also trapped. The fact gives us a clue that the size and electrical property of the substituent group will affect the enzymatic activity of related enzymes involved in NOS biosynthesis pathway. ${ }^{[24]}$ However, the relationship between the size and electrical property of the substituent group in MIA and the substrate tolerance of enzymes involved in NOS biosynthesis pathway remains undefined. Herein, we provide experimental evidence that substrate tolerance of enzymes involved in NOS biosynthesis pathway by using MIA analogues with different size and chemical property substituent group, such as $\mathrm{F}, \mathrm{Cl}$, $\mathrm{CH}_{3}, \mathrm{NO}_{2}$ and $\mathrm{CF}_{3}$.

\section{Results and discussion}

For MIA analogues preparation, an efficient two-step chemical synthesis route was developed. ${ }^{[24]}$ Briefly, 2-, 3-, 4-substituted 1-(2-bromophenyl)ethan-1-ones were reacted with ethyl isocyanoacetate in the presence of $\mathrm{Cs}_{2} \mathrm{CO}_{3}$ and $\mathrm{CuI}$, resulting in substituted indole-2-carboxylic acid esters in $85 \% \sim 90 \%$ yield. The substituted-MIA esters were further hydrolyzed by $\mathrm{NaOH}$ followed by acidification, furnishing substituted-MIA in $80 \% \sim 88 \%$ yield (Scheme 2, A). The substituted-MIA was exogenously fed into the fermentation broth with a NosL-deficient mutant strain, $\Delta n o s L$, in which the biosynthetic route to MIA was blocked. The fermentation products were analyzed by high pressure liquid chromatography (HPLC) (Scheme 2, B).

5-F-MIA was firstly exogenously fed into the fermentation broth with $\Delta$ nosL mutant strain (Figure 2, III). The target NOS analogue 5'-F-NOS and an unexpected compound 5'-F-NOSint were co-produced. HR-ESI-MS data established the molecular formula as $\mathrm{C}_{51} \mathrm{H}_{43} \mathrm{FN}_{13} \mathrm{O}_{12} \mathrm{~S}_{6}$ $\left([\mathrm{M}+\mathrm{H}]^{+}\right.$, calcd 1240.1457 , found 1240.1436) and $\mathrm{C}_{53} \mathrm{H}_{45} \mathrm{FN}_{13} \mathrm{O}_{12} \mathrm{~S}_{6}\left([\mathrm{M}+\mathrm{H}]^{+}\right.$, calcd 1266.1613, found<smiles>[R1]c1ccc(C(C)=O)c(Br)c1</smiles>

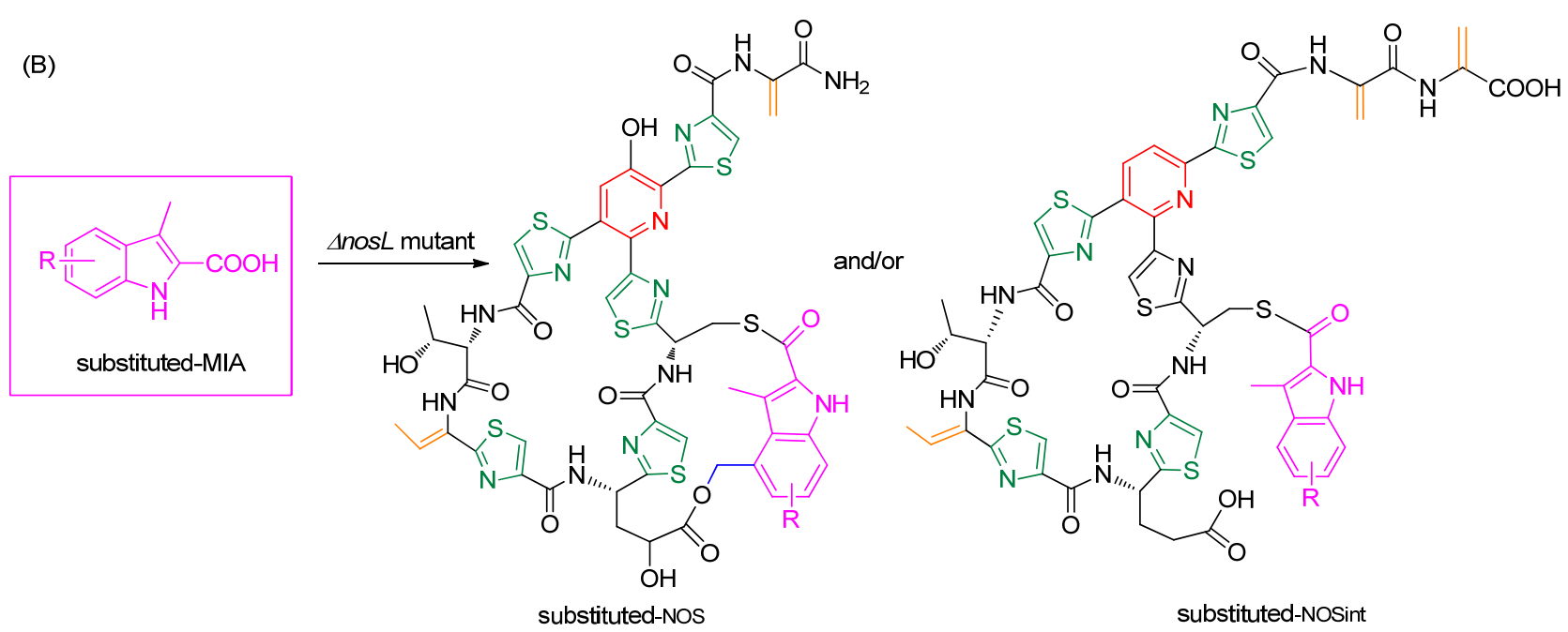

Scheme 2 (A) Chemical synthesis of the substituted-MIA and (B) enzymes involved in NOS biosynthesis pathway to generate NOS analogues or NOSint in NosL mutant, by chemically feeding substituted-MIA 


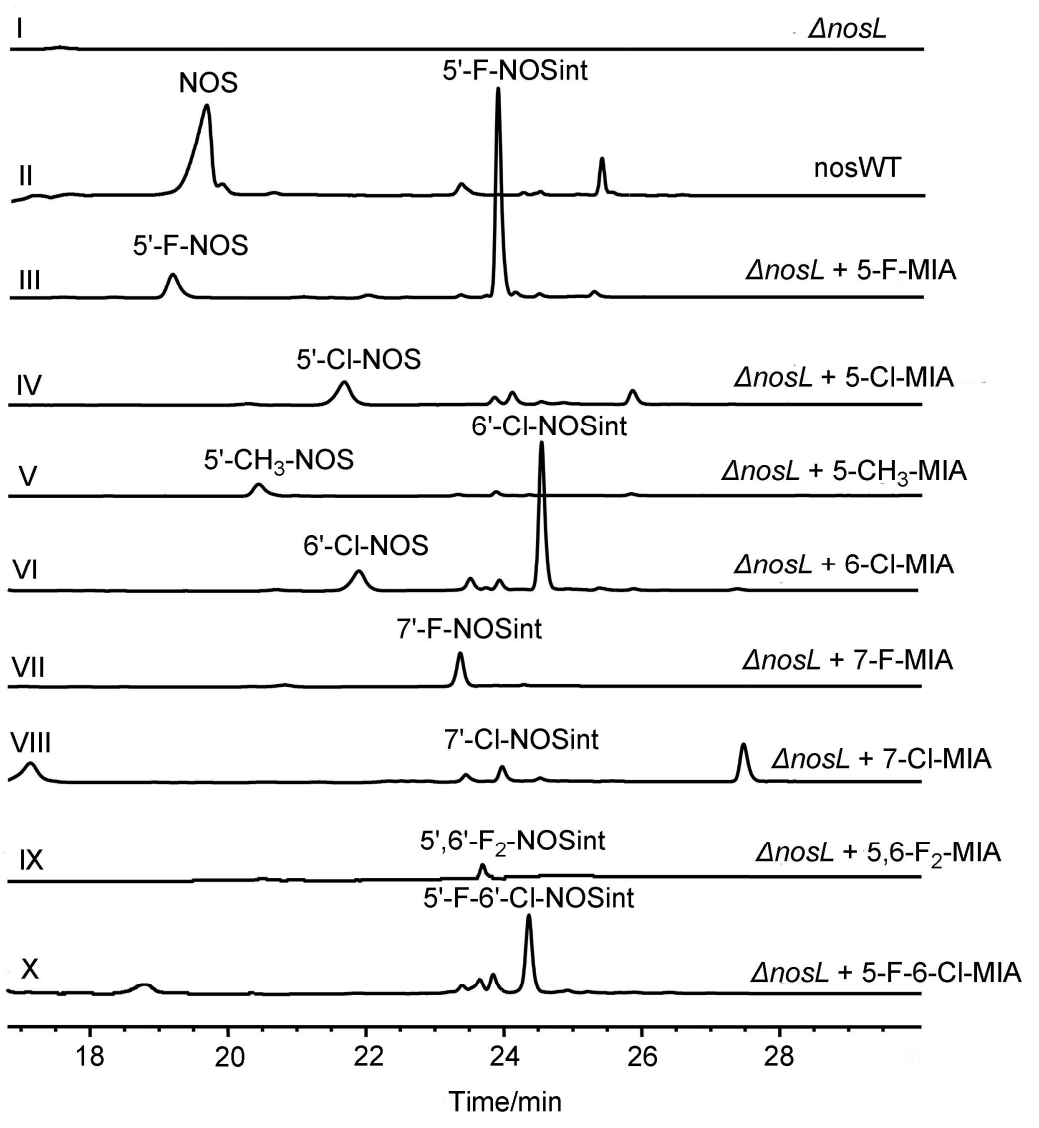

Figure 2 HPLC analysis of the fermentation products from the wild-type NOS-producing strain streptomyces actuosus ATCC25421 (II), the nosL-deficient mutant strain $\triangle$ nosL (I) and $\triangle$ nosL complemented by chemically feeding substituted-MIA (III $\sim \mathrm{X}$ ).

1266.1578) respectively. As shown in Figure 2 (III), the output of 5'-F-NOSint is more than that of 5'-F-NOS. Regarding to the fact that electronegativity of $\mathrm{F}(4.0)$ is higher than $\mathrm{H}(2.1)$ while atomic radius of $\mathrm{F}(0.071 \mathrm{~nm})$ is similar to $\mathrm{H}(0.079 \mathrm{~nm})$, the introduction of a fluorine atom at $\mathrm{C}(5)$ of MIA will reduce the electron cloud density of MIA and hence affect losing an electron to generate the resulting electrophilic aryl cation intermediate (Scheme 3), and thus partly side-ring-opening intermediate was accumulated. Fortunately, the side-ring-opening intermediate can be tolerated by $\mathrm{Nos} \mathrm{O}$ and then be enzymatically transformed to form 5'-F-NOSint. Since the substrates of tailoring enzymes NosA, NosB and NosC feature the closure of the side ring, 5'-F-NOSint can't be enzymatically transformed by these three enzymes. ${ }^{[22]}$

When 5-Cl-MIA was fed into the fermentation broth with $\triangle$ nosL mutant strain, the target NOS analogue, 5'-Cl-NOS was produced, and HR-ESI-MS data established the molecular formula as $\mathrm{C}_{51} \mathrm{H}_{43} \mathrm{ClN}_{13} \mathrm{O}_{12} \mathrm{~S}_{6}([\mathrm{M}+$ $\mathrm{H}]^{+}$, calcd 1256.1161, found 1256.1154). 5'-Cl-NOSint, however, was not found in the fermentation products (Figure 2, IV). The electronegativity of $\mathrm{Cl}$ (3.2) is a little weaker than that of $\mathrm{F}$ (4.0) while atomic radius of $\mathrm{Cl}$ $(0.099 \mathrm{~nm})$ is similar to $\mathrm{F}(0.071 \mathrm{~nm})$, reveals that the electron cloud density adjacent to $\mathrm{C}(4)$ have the key effect on the NosN enzymatic activity. When 5- $\mathrm{CH}_{3}-\mathrm{MIA}$ was exogenously fed into the fermentation broth with $\Delta n o s L \mathrm{mu}-$ tant strain, the target NOS analogue, 5'- $\mathrm{CH}_{3}-\mathrm{NOS}$, was produced and HR-ESI-MS data established the molecular formula as $\mathrm{C}_{52} \mathrm{H}_{46} \mathrm{~N}_{13} \mathrm{O}_{12} \mathrm{~S}_{6}\left([\mathrm{M}+\mathrm{H}]^{+}\right.$, calcd 1236.1708, found 1236.1626). The $\mathrm{CH}_{3}$ is an electron donor group which will facilitate losing an electron to form the resulting electrophilic aryl cation intermediate (Scheme 3). The above experiments show that the chemical property of substituent group at $\mathrm{C}(5)$ is the main barrier to affect NosN enzymatic fuction.

For 5- $\mathrm{CF}_{3}-\mathrm{MIA}$ and 5- $\mathrm{NO}_{2}-\mathrm{MIA}$, the target NOS analogues or NOSint analogues, were not found in the fermentation products. The electronegativity of $\mathrm{CF}_{3}$ (3.6) or $\mathrm{NO}_{2}$ (3.4) is a little weaker than the electronegativity of $\mathrm{F}$ (4.0) while atomic radius of $\mathrm{CF}_{3}$ or $\mathrm{NO}_{2}$ is much larger than that of $\mathrm{F}^{\left[{ }^{[25]}\right.}$ On the one hand, their steric hindrance might hinder methylene radical addition to C(4) of MIA to give an aryl radical intermediate (Scheme 3), and thus might hinder the following dehydratase (NosD and NosE) and azacyclase (NosO). On the other hand, MIA is activated and uploaded by NosI, NosJ, and NosK, and the above results can't deny the possibility that introduction $\mathrm{CF}_{3}$ or $\mathrm{NO}_{2}$ into $\mathrm{C}(5)$ of MIA might affect enzymatic activities of NosI, NosJ, and NosK.

When 6-Cl-MIA was exogenously fed into the fermentation broth with $\triangle n o s L$ mutant strain, 6'-chloro-NOS and 6'-Cl-NOSint, were co-produced. HR-ESI-MS data estab- 


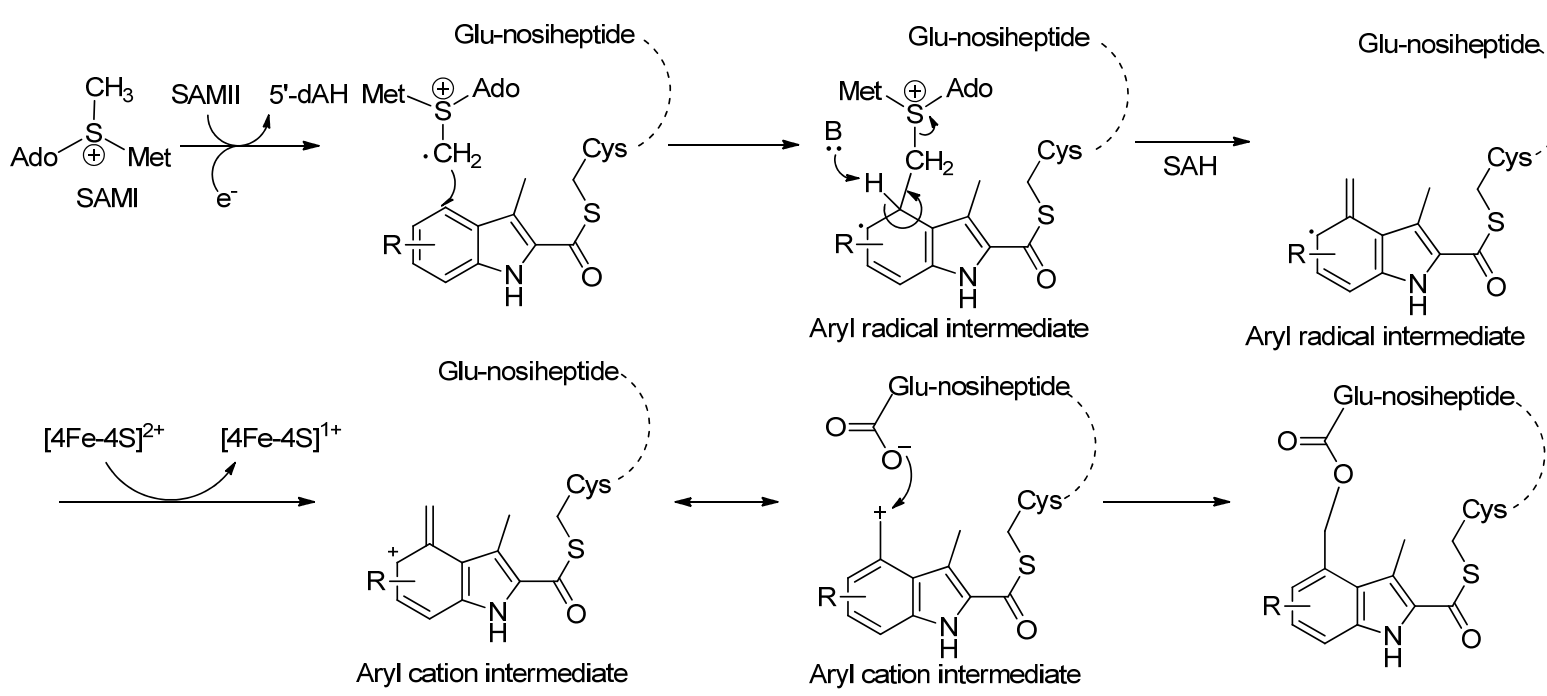

Scheme 3 Proposed mechanism of NosN

lished the molecular formula as $\mathrm{C}_{51} \mathrm{H}_{43} \mathrm{ClN}_{13} \mathrm{O}_{12} \mathrm{~S}_{6}([\mathrm{M}+$ $\mathrm{H}]^{+}$, calcd 1256.1161, found 1256.1141) and $\mathrm{C}_{53} \mathrm{H}_{45} \mathrm{Cl}-$ $\mathrm{N}_{13} \mathrm{O}_{12} \mathrm{~S}_{6}\left([\mathrm{M}+\mathrm{H}]^{+}\right.$, calcd 1282.1318 , found 1282.1290$)$ respectively. As shown in Figure 2 (VI), the output of 6 -Cl-NOSint is more than 6'-Cl-NOS, revealing that introduction of a chlorine atom at $\mathrm{C}(6)$ of MIA, perhaps interferes the enzymatic function of NosN via the steric hindrance.

When 7-F-MIA or 7-Cl-MIA was exogenously fed into the fermentation broth with $\Delta$ nosL mutant strain, 7'-F-NOSint or 7'-Cl-NOSint was respectively produced. HR-ESI-MS data established the molecular formula as $\mathrm{C}_{53} \mathrm{H}_{45} \mathrm{FN}_{13} \mathrm{O}_{12} \mathrm{~S}_{6}\left([\mathrm{M}+\mathrm{H}]^{+}\right.$, calcd 1266.1613, found $1266.1591)$ or $\mathrm{C}_{53} \mathrm{H}_{45} \mathrm{ClN}_{13} \mathrm{O}_{12} \mathrm{~S}_{6}\left([\mathrm{M}+\mathrm{H}]^{+}\right.$, calcd 1282.1318, found 1282.1274) respectively. Figure 2 shows that 7'-F-NOSint and 7'-Cl-NOSint are the main product while the output of 7'-Cl-NOSint is somewhat lower. The above result reveals that the steric hindrance at $\mathrm{C}(7)$ of MIA may have the key effect on NosN enzymatic activity. Furthermore, we got no product when larger substituent group on MIA, such as $7-\mathrm{CF}_{3}-\mathrm{MIA}$ or $7-\mathrm{NO}_{2}$-MIA, was fed into the fermentation broth. The possible mechanism of activation and upload of $7-\mathrm{CF}_{3}-\mathrm{MIA}$ or $7-\mathrm{NO}_{2}-\mathrm{MIA}$ is similar to that of $5-\mathrm{NO}_{2}$-MIA.

For disubstituted MIA, When 5,6- $\mathrm{F}_{2}-\mathrm{MIA}$ or 5-F-6Cl-MIA was exogenously fed into the fermentation broth with $\Delta$ nosL mutant strain, 5',6'-F - NOSint or 5'-F-6'-ClNOSint was respectively produced. HR-ESI-MS data established the molecular formula as $\mathrm{C}_{53} \mathrm{H}_{44} \mathrm{~F}_{2} \mathrm{~N}_{13} \mathrm{O}_{12} \mathrm{~S}_{6}$ $\left([\mathrm{M}+\mathrm{H}]^{+}\right.$, calcd 1284.1519, found 1284.1490) or $\mathrm{C}_{53} \mathrm{H}_{44} \mathrm{ClFN}_{13} \mathrm{O}_{12} \mathrm{~S}_{6}\left([\mathrm{M}+\mathrm{H}]^{+}\right.$, calcd 1300.1224, found 1300.1166) respectively. Figure 2 (IX and X) shows that the output of 5'-F-6'-Cl-NOSint is much more than that of $5^{\prime}, 6^{\prime}-F_{2}-N O S i n t$. The above result reveals that the dual strong negative inductive effect at $\mathrm{C}(5)$ or strong negative inductive effect at $C(5)$ plus the steric hindrance at $C(6)$ of MIA may have the key effect on NosN enzymatic function to generate an aryl radical intermediate (Scheme 3).
The target NOS analog, 9'- $\mathrm{CH}_{3}-\mathrm{NOS}$, was produced when 9- $\mathrm{CH}_{3}$-MIA was exogenously fed into the fermentation broth with $\Delta$ nosL mutant strain. HR-ESI-MS data established the molecular formula as $\mathrm{C}_{52} \mathrm{H}_{46} \mathrm{~N}_{13} \mathrm{O}_{12} \mathrm{~S}_{6}$ ([ $\mathrm{M}+$ $\mathrm{H}]^{+}$, calcd 1236.1708, found 1236.1695). 9'- $\mathrm{CH}_{3}-\mathrm{NOS}$ is the main product and 9'- $\mathrm{CH}_{3}-\mathrm{NOSint}$ was not found in the fermentation products. Considering the distance, the influence of $C(9)$ substituent group on MIA enzymatic transformations by NosN is negligible. However, no product was got when 9-Ph-5-Cl-MIA was fed into the fermentation broth and the possible mechanism of activation and upload of 9-Ph-5-Cl-MIA is similar to that of 5-CF 3 -MIA.

\section{Conclusions}

Although MIA generation is independent biotransformation process through action of NosL, which will be recognized, activated and tolerated by at least ten enzymes before it becomes mature NOS. Although NosI, NosJ and NosK perform the activation of the MIA and upload it to the intermediate, our results show that these three enzyme's functions might intervene by the larger substituent groups, such as $\mathrm{CF}_{3}$ or $\mathrm{NO}_{2}$ through steric hindrance. However, the chemical property and steric hindrance of substituent group of MIA are the main aspects to affect NosN enzymatic function and the cumulative negative inductive effect of the multisubstituted groups can also affect NosN enzymatic function. The bioengineering of NosI, NosJ, NosK and NosN, based on the analysis of their protein crystal structure, will help to broaden their substrate tolerance and hence are beneficial to structural diversity bioproduction of NOS analogues.

Under the global antibiotic resistance crisis and urgent need for antibiotics with novel mechanisms of action, our work not only explored the substrate tolerance of related enzymes involved in NOS biosynthesis pathway, but also was expected to obtain NOS analogues via mutational biosynthesis. Besides, our work provided valuable information for using directed evolution technology to improve 
the substrate tolerance of enzymes in NOS biosynthesis and to expand the use of NOS-producing bacteria to obtain more analogues, which is difficult to access solely by chemical synthesis.

\section{Experimental section}

\subsection{Experiment procedures and product characteri- zation}

Analytical thin layer chromatography (TLC) was performed on $0.25 \mathrm{~mm}$ silica gel plates (Qingdao Haiyang Chemical China), and the compounds were visualized with a UV light at $254 \mathrm{~nm}$. Flash chromatography was performed on silica gel 200 300 mesh (purchased from Qingdao Haiyang Chemical China) with commercial solvents. The ${ }^{1} \mathrm{H}$ NMR and ${ }^{13} \mathrm{C}$ NMR spectra were recorded on a Bruker AM 500 spectrometer $(500,125,470 \mathrm{MHz}$ for ${ }^{1} \mathrm{H}$ NMR, ${ }^{13} \mathrm{C}$ NMR and ${ }^{19} \mathrm{~F}$ NMR, respectively) and are internally referenced to residual solvent signals (note: $\mathrm{CDCl}_{3}$ referenced at $\delta 7.26$ and 77.00 in ${ }^{1} \mathrm{H}$ NMR and ${ }^{13} \mathrm{C}$ NMR, respectively; DMSO- $d_{6}$ referenced at $\delta 2.50$ and 39.52 in ${ }^{1} \mathrm{H}$ NMR and ${ }^{13} \mathrm{C}$ NMR, respectively). Highresolution mass spectrometry (HRMS) was recorded on an Agilent Q-TOF spectrometer. Melting point was recorded on Hanon MP-420 automatic melting point meter. Commercial reagents and solvents were used as received, unless otherwise stated. 5-F-MIA, 7-F-MIA, 5- $\mathrm{CH}_{3}-\mathrm{MIA}, 5-\mathrm{NO}_{2}-$ MIA, 7- $\mathrm{NO}_{2}$-MIA, 9- $\mathrm{CH}_{3}$-MIA and 9-Ph-5-Cl-MIA were purchased from Cambridge, other MIA analogues were synthesized. Organic solution was concentrated under reduced pressure on an Eyela rotary evaporator.

4.2 Chemical synthesis of ethyl substituted 3-methyl-1H-indole-2-carboxylate

Substituted 1-(2-bromo-4-fluorophenyl)ethan-1-one (10.0 mmol), $\mathrm{Cs}_{2} \mathrm{CO}_{3}(20.0 \mathrm{mmol}), \mathrm{CuI}(1.0 \mathrm{mmol})$ and dimethyl sulfoxide (DMSO, $10 \mathrm{~mL}$ ) were added together into a reacting tube under nitrogen atmosphere. Then ethyl isocyanoacetate $(11.0 \mathrm{mmol})$ was slowly added and the mixture was stirred at $50{ }^{\circ} \mathrm{C}$. Once the reaction finished, ethyl acetate $(100 \mathrm{~mL})$ and water $(40 \mathrm{~mL})$ were added. The organic phase was separated, dried over sodium sulphate and evaporated in vacuum. The residue was loaded on silica gel column and purified to get ethyl substituted 3 -methyl- $1 H$-indole-2-carboxylate in $80 \% \sim 90 \%$ yield.

Ethyl 5-chloro-3-methyl-1H-indole-2-carboxylate (b1): ${ }^{[26]}$ white solid, 2.13 g, 90\% yield. m.p. $153 \sim 154{ }^{\circ} \mathrm{C}$ (lit. $\left.{ }^{[30]} 152 \sim 154{ }^{\circ} \mathrm{C}\right) ;{ }^{1} \mathrm{H}$ NMR $\left(\mathrm{CDCl}_{3}, 500 \mathrm{MHz}\right) \delta: 8.80$ (br, $1 \mathrm{H}), 7.62(\mathrm{~s}, 1 \mathrm{H}), 7.31 \sim 7.23(\mathrm{~m}, 2 \mathrm{H}), 4.44(\mathrm{q}, J=7.2$ $\mathrm{Hz}, 2 \mathrm{H}), 2.56$ (s, 3H), 1.43 (t, $J=7.2 \mathrm{~Hz}, 3 \mathrm{H})$.

Ethyl 6-chloro-3-methyl-1H-indole-2-carboxylate (b2): ${ }^{[28]}$ white solid, $2.08 \mathrm{~g}, 88 \%$ yield. m.p. $158 \sim 159{ }^{\circ} \mathrm{C}$ (lit. $\left.{ }^{[31]} 159 \sim 160{ }^{\circ} \mathrm{C}\right) ;{ }^{1} \mathrm{H} \mathrm{NMR}\left(\mathrm{CDCl}_{3}, 500 \mathrm{MHz}\right) \delta: 8.80$ (br, $1 \mathrm{H}), 7.56$ (d, $J=8.4 \mathrm{~Hz}, 1 \mathrm{H}), 7.35$ (d, $J=1.5 \mathrm{~Hz}, 1 \mathrm{H})$, $7.10(\mathrm{dd}, J=8.4,1.8 \mathrm{~Hz}, 1 \mathrm{H}), 4.44$ (q, $J=7.2 \mathrm{~Hz}, 2 \mathrm{H})$, $2.58(\mathrm{~s}, 3 \mathrm{H}), 1.43(\mathrm{t}, J=7.2 \mathrm{~Hz}, 3 \mathrm{H})$.

Ethyl 7-chloro-3-methyl-1H-indole-2-carboxylate (b3): ${ }^{[26]}$ white solid, 2.02 g, $85 \%$ yield. m.p. $156 \sim 157{ }^{\circ} \mathrm{C}$;
${ }^{1} \mathrm{H}$ NMR $\left(\mathrm{CDCl}_{3}, 500 \mathrm{MHz}\right) \delta: 8.81(\mathrm{br}, 1 \mathrm{H}), 7.56(\mathrm{~d}, J=$ $8.1 \mathrm{~Hz}, 1 \mathrm{H}), 7.32(\mathrm{~d}, J=7.5 \mathrm{~Hz}, 1 \mathrm{H}), 7.08(\mathrm{t}, J=7.8 \mathrm{~Hz}$, $1 \mathrm{H}), 4.44$ (q, $J=7.2 \mathrm{~Hz}, 2 \mathrm{H}), 2.60(\mathrm{~s}, 3 \mathrm{H}), 1.43$ (t, $J=7.2$ $\mathrm{Hz}, 3 \mathrm{H})$.

Ethyl 5,6-difluoro-3-methyl- $1 H$-indole-2-carboxylate $(\mathbf{b}-4):^{[27]}$ white solid, $2.03 \mathrm{~g}, 85 \%$ yield. m.p. $138 \sim$ $139{ }^{\circ} \mathrm{C} ;{ }^{1} \mathrm{H} \mathrm{NMR}\left(\mathrm{CDCl}_{3}, 500 \mathrm{MHz}\right) \delta: 8.78$ (br, $\left.1 \mathrm{H}\right)$, $7.40 \sim 7.34(\mathrm{~m}, 1 \mathrm{H}), 7.16 \sim 7.11(\mathrm{~m}, 1 \mathrm{H}), 4.42$ (q, $J=7.2$ $\mathrm{Hz}, 2 \mathrm{H}), 2.54$ (s, 3H), $1.43(\mathrm{t}, J=7.2 \mathrm{~Hz}, 3 \mathrm{H})$.

Ethyl 6-chloro-5-fluoro-3-methyl- $1 \mathrm{H}$-indole-2-carboxylate $(\mathbf{b}-5){ }^{\left[{ }^{[26]}\right.}$ white solid, $2.09 \mathrm{~g}, 82 \%$ yield. m.p. 163 $164{ }^{\circ} \mathrm{C} ;{ }^{1} \mathrm{H} \mathrm{NMR}\left(\mathrm{CDCl}_{3}, 500 \mathrm{MHz}\right) \delta: 8.67$ (br, $\left.1 \mathrm{H}\right)$, $7.41 \sim 7.35(\mathrm{~m}, 2 \mathrm{H}), 4.44(\mathrm{q}, J=7.2 \mathrm{~Hz}, 2 \mathrm{H}), 2.54(\mathrm{~s}, 3 \mathrm{H})$, $1.43(\mathrm{t}, J=7.2 \mathrm{~Hz}, 3 \mathrm{H})$.

Ethyl 3-methyl-5-(trifluoromethyl)- $1 H$-indole-2-carboxylate (b-6): ${ }^{[29]}$ white solid, $2.17 \mathrm{~g}, 80 \%$ yield. m.p. 183 $184{ }^{\circ} \mathrm{C} ;{ }^{1} \mathrm{H}$ NMR $\left(\mathrm{CDCl}_{3}, 500 \mathrm{MHz}\right) \delta: 9.02$ (br, 1H), 7.96 (s, 1H), 7.53 (dd, $J=8.4,1.2 \mathrm{~Hz}, 1 \mathrm{H}), 7.44$ (d, $J=8.4 \mathrm{~Hz}$, $1 \mathrm{H}), 4.44$ (q, $J=7.2 \mathrm{~Hz}, 2 \mathrm{H}), 2.60$ (s, 3H), 1.43 (t, $J=7.2$ $\mathrm{Hz}, 3 \mathrm{H})$.

Ethyl 3-methyl-7-(trifluoromethyl)- $\mathrm{H}$-indole-2-carboxylate (b-7): ${ }^{[28]}$ white solid, 2.22 g, 82\% yield. m.p. 187 $188{ }^{\circ} \mathrm{C} ;{ }^{1} \mathrm{H} \mathrm{NMR}\left(\mathrm{CDCl}_{3}, 500 \mathrm{MHz}\right) \delta$ : 8.92 (br, $\left.1 \mathrm{H}\right), 7.83$ $(\mathrm{d}, J=8.1 \mathrm{~Hz}, 1 \mathrm{H}), 7.57$ (d, $J=7.5 \mathrm{~Hz}, 1 \mathrm{H}), 7.26 \sim 7.18$ $(\mathrm{m}, 1 \mathrm{H}), 4.44(\mathrm{q}, J=7.2 \mathrm{~Hz}, 2 \mathrm{H}), 2.62(\mathrm{~s}, 3 \mathrm{H}), 1.44(\mathrm{t}, J=$ $7.2 \mathrm{~Hz}, 3 \mathrm{H})$.

\subsection{Chemical synthesis of substituted-MIA}

Ethyl substituted 3-methyl-1H-indole-2-carboxylate (5 $\mathrm{mmol}), \mathrm{NaOH}(50 \mathrm{mmol})$ and $\mathrm{EtOH}(20 \mathrm{~mL})$ were added together into a round-bottom flask and the mixture was refluxed overnight. After the reaction was finished, the solvent was evaporated in vacuum and the residue was redissolved in water $(20 \mathrm{~mL})$. Ethyl acetate $(40 \mathrm{~mL})$ was added and the aqueous phase was separated and acidification to $\mathrm{pH} 3.5$ by using $1 \mathrm{~mol} / \mathrm{L} \mathrm{HCl}$. Ethyl acetate $(40$ $\mathrm{mL}$ ) was added and the organic phase was separated, dried over sodium sulphate and evaporated in vacuum to give substituted-MIA in $80 \% \sim 88 \%$ yield.

5-Chloro-3-methyl-1 $H$-indole-2-carboxylic acid (a-1): $0.88 \mathrm{~g}, 85 \%$ yield. ${ }^{1} \mathrm{H}$ NMR $\left(500 \mathrm{MHz}, \mathrm{DMSO}-d_{6}\right) \delta$ : 13.05 (s, 1H), 11.59 (s, 1H), 7.70 (dd, $J=2.0 \mathrm{~Hz}, 1 \mathrm{H}), 7.39$ (dd, $J=8.7,0.6 \mathrm{~Hz}, 1 \mathrm{H}), 7.24$ (dd, $J=8.7,2.1 \mathrm{~Hz}, 1 \mathrm{H})$, $2.50(\mathrm{~s}, 3 \mathrm{H}) ;{ }^{13} \mathrm{C}$ NMR $\left(125 \mathrm{MHz}, \mathrm{DMSO}-d_{6}\right) \delta: 163.74(\mathrm{~s}$, C-8), 134.86 (s, C-7a), 129.28 (s, C-3a), 126.03 (s, C-5), 125.13 (s, C-2), 124.24 (s, C-3), 119.93 (s, C-6), 117.81 (s, C-4), 114.40 (s, C-7), 10.10 (s, C-9); HRMS(EI) calcd $\mathrm{C}_{10} \mathrm{H}_{7} \mathrm{ClNO}_{2}(\mathrm{M}-\mathrm{H})^{-}$208.0171, found 208.0171.

6-Chloro-3-methyl-1 $H$-indole-2-carboxylic acid (a-2): $0.89 \mathrm{~g}, 86 \%$ yield. ${ }^{1} \mathrm{H}$ NMR (500 MHz, DMSO- $\left.d_{6}\right) \delta$ : 13.05 (s, 1H), 11.53 (s, 1H), 7.65 (d, $J=8.6 \mathrm{~Hz}, 1 \mathrm{H}), 7.41$ $(\mathrm{d}, J=1.9 \mathrm{~Hz}, 1 \mathrm{H}), 7.06(\mathrm{dd}, J=8.6,1.9 \mathrm{~Hz}, 1 \mathrm{H}), 2.52$ (s, $3 \mathrm{H}) ;{ }^{13} \mathrm{C}$ NMR $\left(125 \mathrm{MHz}, \mathrm{DMSO}-d_{6}\right) \delta: 163.42(\mathrm{~s}, \mathrm{C}-8)$, 136.39 (s, C-7a), 129.36 (s, C-6), 126.75 (s, C-3a), 125.20 (s, C-2), 122.06 (s, C-3), 119.91 (s, C-5), 118.12 (s, C-4), 111.75 (s, C-7), 9.8(s, C-9); HRMS(EI) calcd $\mathrm{C}_{10} \mathrm{H}_{7} \mathrm{ClNO}_{2}$ $(\mathrm{M}-\mathrm{H})^{-}$208.0171, found 208.0169. 
7-Chloro-3-methyl-1H-indole-2-carboxylic acid (a-3): $0.86 \mathrm{~g}, 83 \%$ yield. ${ }^{1} \mathrm{H}$ NMR (500 MHz, DMSO-d $\left.d_{6}\right) \delta$ : $13.10(\mathrm{~s}, 1 \mathrm{H}), 11.45(\mathrm{~s}, 1 \mathrm{H}), 7.63(\mathrm{dd}, J=8.0,0.8 \mathrm{~Hz}, 1 \mathrm{H})$, 7.33 (dd, $J=7.5,0.9 \mathrm{~Hz}, 1 \mathrm{H}), 7.07$ (t, $J=7.8 \mathrm{~Hz}, 1 \mathrm{H}), 2.52$ $(\mathrm{s}, 3 \mathrm{H}) ;{ }^{13} \mathrm{C}$ NMR $\left(125 \mathrm{MHz}, \mathrm{DMSO}-d_{6}\right) \delta$ : $163.61(\mathrm{~s}$, C-8), 133.62 (s, C-7a), 130.25 (s, C-3a), 126.26 (s, C-2), 124.73 (s, C-3), 120.66 (s, C-5), 119.80 (s, C-7), 119.57 (s, C-6), 117.02 (s, C-4), 10.42 (s, C-9); HRMS(EI) calcd $\mathrm{C}_{10} \mathrm{H}_{7} \mathrm{ClNO}_{2}(\mathrm{M}-\mathrm{H})^{-}$208.0171, found 208.0173.

5,6-Difluoro-3-methyl- $1 H$-indole-2-carboxylic acid (a-4): $0.84 \mathrm{~g}, 80 \%$ yield. ${ }^{1} \mathrm{H}$ NMR (500 MHz, DMSO- $d_{6}$ ) $\delta: 12.99(\mathrm{~s}, 1 \mathrm{H}), 11.55(\mathrm{~s}, 1 \mathrm{H}), 7.66(\mathrm{dd}, J=11.1,8.1 \mathrm{~Hz}$, $1 \mathrm{H}), 7.27(\mathrm{dd}, J=11.0,7.0 \mathrm{~Hz}, 1 \mathrm{H}), 2.48(\mathrm{~s}, 3 \mathrm{H}) ;{ }^{13} \mathrm{C}$ NMR (125 MHz, DMSO- $\left.d_{6}\right) \delta$ : 162.98 (s, C-8), 148.84 (d, $J=240$, C-5), 145.55 (d, $J=240$, C-6), 131.27 (d, $J=10.8$ $\mathrm{Hz}, \mathrm{C}-7 \mathrm{a}), 125.81$ (d, $J=3.8 \mathrm{~Hz}, \mathrm{C}-3 \mathrm{a}), 123.24$ (d, $J=7.8$ $\mathrm{Hz}, \mathrm{C}-2$ ), 118.23 (m, C-3), 106.92 (d, $J=18.5 \mathrm{~Hz}, \mathrm{C}-4)$, 99.63 (d, $J=21.4 \mathrm{~Hz}, \mathrm{C}-7), 9.75$ (s, C-9); ${ }^{19} \mathrm{~F}$ NMR (470 $\left.\mathrm{MHz}, \mathrm{DMSO}-d_{6}\right) \delta$ : $-140.25(\mathrm{dt}, J=20.3,9.5 \mathrm{~Hz})$, -147.38 (ddd, $J=21.6,11.2,7.0 \mathrm{~Hz}$ ); HRMS(EI) calcd $\mathrm{C}_{10} \mathrm{H}_{6} \mathrm{~F}_{2} \mathrm{NO}_{2}(\mathrm{M}-\mathrm{H})^{-}$210.0372, found 210.0372 .

6-Chloro-5-fluoro-3-methyl-1H-indole-2-carboxylic acid (a-5): $0.93 \mathrm{~g}, \quad 83 \%$ yield. ${ }^{1} \mathrm{H}$ NMR $(500 \mathrm{MHz}$, DMSO- $\left.d_{6}\right) \delta$ : $13.09(\mathrm{~s}, 1 \mathrm{H}), 11.59(\mathrm{~s}, 1 \mathrm{H}), 7.65(\mathrm{~d}, J=10.1$ $\mathrm{Hz}, 1 \mathrm{H}), 7.48$ (d, $J=6.4 \mathrm{~Hz}, 1 \mathrm{H}), 2.48(\mathrm{~s}, 3 \mathrm{H}) ;{ }^{13} \mathrm{C} \mathrm{NMR}$ $\left(125 \mathrm{MHz}, \mathrm{DMSO}-d_{6}\right) \delta: 163.06(\mathrm{~s}, \mathrm{C}-8), 152.66(\mathrm{~d}, J=$ 240, C-5), 150.78 (s, C-7a), 132.31 (s, C-3a), 126.4 (s, C-2), 117.97 (d, $J=5.2, \mathrm{C}-3), 117.16$ (d, $J=21.8, \mathrm{C}-4)$, 113.23 (s, C-7), 106.35 (d, $J=22.7, \mathrm{C}-6), 9.70$ (s, C-9); ${ }^{19} \mathrm{~F}$ NMR (470 MHz, DMSO- $\left.d_{6}\right) \delta:-127.19$ (dd, $J=10.2$, $6.2 \mathrm{~Hz}) ; \mathrm{HRMS}(\mathrm{EI})$ calcd $\mathrm{C}_{10} \mathrm{H}_{6} \mathrm{ClFNO}_{2}(\mathrm{M}-\mathrm{H})$ 226.0077, found 226.0075.

3-Methyl-5-(trifluoromethyl)- $1 H$-indole-2-carboxylic acid (a-6): $1.02 \mathrm{~g}, 85 \%$ yield. ${ }^{1} \mathrm{H}$ NMR $(500 \mathrm{MHz}$, DMSO- $\left.d_{6}\right) \delta: 13.17(\mathrm{~s}, 1 \mathrm{H}), 11.84(\mathrm{~s}, 1 \mathrm{H}), 8.04(\mathrm{dd}, J=$ 1.9, $1.0 \mathrm{~Hz}, 1 \mathrm{H}), 7.63 \sim 7.45(\mathrm{~m}, 2 \mathrm{H}), 2.57(\mathrm{~s}, 3 \mathrm{H}) ;{ }^{13} \mathrm{C}$ NMR (125 MHz, DMSO- $\left.d_{6}\right) \delta: 163.21$ (s, C-8), 137.34 (s, C-7a), 127.05 (s, C-3a), 126.19 (s, C-2), 125.42(q, $J=$ $272.2 \mathrm{~Hz}, \mathrm{C}-10$ ), 120.62 (q, $J=3.3 \mathrm{~Hz}, \mathrm{C}-5$ ), 120.06 (d, $J=31.1 \mathrm{~Hz}, \mathrm{C}-3), 118.88$ (s, C-4), 118.32 (d, $J=4.4, \mathrm{C}-6)$, 113.21 (s, C-7), 9.58 (s, C-9); ${ }^{19} \mathrm{~F}$ NMR (470 MHz, DMSO-d $\left.d_{6}\right) \delta$ : $-58.74(\mathrm{~s})$; HRMS(EI) calcd $\mathrm{C}_{11} \mathrm{H}_{7} \mathrm{~F}_{3} \mathrm{NO}_{2}$ $(\mathrm{M}-\mathrm{H})^{-}$242.0434, found 242.0432.

3-Methyl-7-(trifluoromethyl)- $1 \mathrm{H}$-indole-2-carboxylic acid (a-7): $0.99 \mathrm{~g}, 82 \%$ yield. ${ }^{1} \mathrm{H}$ NMR $(500 \mathrm{MHz}$, DMSO- $\left.d_{6}\right) \delta: 13.22(\mathrm{~s}, 1 \mathrm{H}), 11.18(\mathrm{~s}, 1 \mathrm{H}), 7.97(\mathrm{dd}, J=$ 8.0, $1.7 \mathrm{~Hz}, 1 \mathrm{H}), 7.62$ (dt, $J=7.4,1.0 \mathrm{~Hz}, 1 \mathrm{H}), 7.23$ (ddd, $J=8.2,7.3,0.8 \mathrm{~Hz}, 1 \mathrm{H}), 2.56(\mathrm{~s}, 3 \mathrm{H}) ;{ }^{13} \mathrm{C} \mathrm{NMR}(125$ MHz, DMSO- $\left.d_{6}\right) \delta: 163.03$ (s, C-8), 130.80 (s, C-7a), 129.88 (s, C-3a), 126.44 (s, C-2), 125.20 (s, C-3), 124.20 (q, $J=273.5 \mathrm{~Hz}, \mathrm{C}-10), 122.39$ (s, C-4,5), 118.76 (d, $J=$ $3.6 \mathrm{~Hz}, \mathrm{C}-5$ ), 113.10 (d, $J=32.7 \mathrm{~Hz}, \mathrm{C}-6,7), 9.63$ (s, C-9); ${ }^{19} \mathrm{~F}$ NMR (470 MHz, DMSO- $\left.d_{6}\right) \delta$ : -59.63 (s); HRMS (EI) calcd $\mathrm{C}_{11} \mathrm{H}_{7} \mathrm{~F}_{3} \mathrm{NO}_{2}(\mathrm{M}-\mathrm{H})^{-}$242.0434, found 242.0434.

\subsection{Fermentation and chemical feeding}

\subsubsection{Fermentation}

For sporulation, the Streptomyces actuosus strains were cultured on MS agar plates (mannitol, $\omega=2.0 \%$; soybean cake meal, $\omega=2.0 \%$; agar, $\omega=2.0 \%$ ) at $30{ }^{\circ} \mathrm{C}$ for $3 \mathrm{~d}$. The $S$. actuosus spores were inoculated into a $500-\mathrm{mL}$ flask containing $100 \mathrm{~mL}$ of primary fermentation medium (sucrose, $\omega=2.0 \%$; corn steep liquor, $\omega=3.0 \%$; peptone, $\left.\omega=0.5 \% ; \mathrm{CaCO}_{3}, \omega=0.5 \% ; \mathrm{pH} 7.2 \sim 7.6\right)$ and incubated at $30{ }^{\circ} \mathrm{C}$ and $220 \mathrm{r} / \mathrm{min}$ for $30 \mathrm{~h}$.

\subsubsection{Chemical feeding}

$0.2 \mathrm{~mL}$ substituted-MIA (1 mmol/L dissolved in DMSO) was fed to $100 \mathrm{~mL}$ fermentation broth of $\Delta n o s L$, which would be incubated at $30{ }^{\circ} \mathrm{C}$ and $220 \mathrm{r} / \mathrm{min}$ for 48 h.

\subsection{Compound analysis}

The fermentation broth was centrifuged, and the supernatant was discarded. The mycelia cake was soaked with acetone and sonicated for $30 \mathrm{~min}$. The acetone sample was then centrifuged for high performance liquidchromatography (HPLC) analysis on an Agilent Zorbax column. The column was eluted with solvents $\mathrm{A}\left(\mathrm{H}_{2} \mathrm{O}+1 \mathrm{mmol} / \mathrm{L}\right.$ $\mathrm{HCOOH})$ and $\mathrm{B}\left(\mathrm{CH}_{3} \mathrm{CN}+1 \mathrm{mmol} / \mathrm{L} \mathrm{HCOOH}\right)$ at a flow rate of $1 \mathrm{~mL} \cdot \mathrm{min}^{-1}$ as follows: $t=0 \mathrm{~min}, \varphi(\mathrm{B})=15 \% ; t=3$ $\min , \varphi(\mathrm{B})=15 \% ; t=6 \mathrm{~min}, \varphi(\mathrm{B})=45 \% ; t=12 \mathrm{~min}$, $\varphi(\mathrm{B})=45 \% ; t=19 \min , \varphi(\mathrm{B})=55 \% ; t=22 \mathrm{~min}, \varphi(\mathrm{B})=$ $85 \% ; t=28 \min , \varphi(\mathrm{B})=85 \% ; t=30 \min , \varphi(\mathrm{B})=15 \%$. UV absorbance was monitored at $330 \mathrm{~nm}$.

Supporting Information ${ }^{1} \mathrm{H}$ NMR and ${ }^{13} \mathrm{C}$ NMR spectra of compounds a-1, a-2, a-3, a-4, a-5, a-6, a-7, and UV absorbance and HRMS analysis of substituted-NOS and substituted-NOSint. The Supporting Information is available free of charge via the Internet at http://sioc-journal.cn.

\section{References}

[1] Newman, D. J.; Cragg, G. M. J. Nat. Prod. 2020, 83, 770.

[2] Just-Baringo, X.; Albericio, F.; Alvarez, M. Angew. Chem., Int. Ed. 2014, 53, 6602.

[3] Bagley, M. C.; Dale, J. W.; Merritt, E. A.; Xiong, X. Chem. Rev. 2005, 105, 685 .

[4] Haste, N. M.; Thienphrapa, W.; Tran, D. N.; Loesgen, S.; Sun, P.; Nam, S.; Jensen, P. R.; Fenical, W.; Sokoulas, G.; Nizet, V.; Hensler, M. E. J. Antibiotics 2012, 65, 593.

[5] Harms, J. M.; Wilson, D. N.; Schluenzen, F.; Connell, S. R.; Stachelhaus, T.; Zaborowska, Z.; Spahn, C. M. T.; Fucini, P. Mol. Cell 2008, 30, 26.

[6] Wison, D. N. Nat. Rev. Microbiol. 2014, 12, 35.

[7] Wojtas, K. P.; Riedrich, M.; Lu, J. Y.; Winter, P.; Winkler, T.; Walter, S.; Arndt, H. D. Angew. Chem., Int. Ed. 2016, 55, 9772.

[8] Arnison, P. G.; Bibb, M. J.; Bierbaum, G.; Bowers, A. A.; Bugni, T. S.; Bulaj, G.; Camarero, J. A.; Campopiano, D. J.; Challis, G. L.; Clardy, J.; Cotter, P. D.; Craik, D. J.; Dawson, M.; Dittmann, E.; Donadio, S.; Dorrestein, P. C.; Entian, K. D.; Fischbach, M. A.; Garavelli, J. S.; Goransson, U.; Gruber, C. W.; Haft, D. H.; Hemscheidt, T. K.; Hertweck, C.; Hill, C.; Horswill, A. R.; Jaspars, M.; Kelly, W. L.; Klinman, J. P.; Kuipers, O. P.; Link, A. J.; Liu, W.; Marahiel, M. A.; Mitchell, D. A.; Moll, G. N.; Moore, B. S.; Muller, R.; Nair, S. K.; Nes, I. F.; Norris, G. E.; Olivera, B. M.; Onaka, H.; 
Patchett, M. L.; Piel, J.; Reaney, M. J.; Rebuffat, S.; Ross, R. P.; Sahl, H. G.; Schmidt, E. W.; Selsted, M. E.; Severinov, K.; Shen, B.; Sivonen, K.; Smith, L.; Stein, T.; Sussmuth, R. D.; Tagg, J. R.; Tang, G. L.; Truman, A. W.; Vederas, J. C.; Walsh, C. T.; Walton, J. D.; Wenzel, S. C.; Willey, J. M.; van der Donk, W. A. Nat. Prod. Rep. 2013, 30, 108.

[9] Yu, Y.; Duan, L.; Zhang, Q.; Liao, R. J.; Ding, Y.; Pan, H. X.; Wendt-Pienkowski, E.; Tang, G. L.; Shen, B.; Liu, W. ACS Chem. Biol. 2009, 4, 855 .

[10] Qiu, Y. P.; Du, Y. A.; Zhang, F.; Liao, R. J.; Zhou, S. X.; Peng, C.; Guo, Y. L.; Liu, W. J. Am. Chem. Soc. 2017, 139, 18186.

[11] Bhandari, D. M.; Fedoseyenko, D.; Begley, T. P. J. Am. Chem. Soc. 2018, 140, 542

[12] Zhang, Q.; Li, Y. X.; Chen, D. D.; Yu, Y.; Duan, L. A.; Shen, B.; Liu, W. Nat. Chem. Biol. 2011, 7, 154.

[13] Badding, E. D.; Grove, T. L.; Gadsby, L. K.; LaMattina, J. W.; Boal, A. K.; Booker, S. J. J. Am. Chem. Soc. 2017, 139, 5896.

[14] Ding, W.; Ji, W. J.; Wu, Y. J.; Wu, R. Z.; Liu, W. Q.; Mo, T. L.; Zhao, J. F.; Ma, X. Y.; Zhang, W.; Xu, P.; Deng, Z. X.; Tang, B. P.; Yu, Y.; Zhang, Q. Nat. Commun. 2017, 8, 437.

[15] LaMattina, J. W.; Wang, B.; Badding, E. D.; Gadsby, L. K.; Grove, T. L.; Booker, S. J. J. Am. Chem. Soc. 2017, 139, 17438.

[16] Wang, B.; LaMattina, J. W.; Marshall, S. L.; Booker, S. J. J. Am. Chem. Soc. 2019, 141, 5788

[17] Qiu, Y. P.; Du, Y. N.; Wang, S. F.; Zhou, S. X.; Guo, Y. L.; Liu, W. Org. Lett. 2019, 21, 1502 .

[18] Hudson, G. A.; Zhang, Z. G.; Tietz, J. I.; Mitchell, D. A.; van der
Donk, W. A. J. Am. Chem. Soc. 2015, 137, 16012.

[19] Cogan, D. P.; Hudson, G. A.; Zhang, Z. G.; Pogorelov, T. V.; van der Donk, W. A.; Mitchell, D. A.; Nair, S. K. Proc. Natl. Acad. Sci. U. S. A. 2017, 114, 12928

[20] Wever, W. J.; Bogart, J. W.; Baccile, J. A.; Chan, A. N.; Schroeder, F. C.; Bowers, A. A. J. Am. Chem. Soc. 2015, 137, 3494.

[21] Yu, Y.; Guo, H.; Zhang, Q.; Duan, L. A.; Ding, Y.; Liao, R. J.; Lei, C.; Shen, B.; Liu, W. J. Am. Chem. Soc. 2010, 132, 16324

[22] Liu, W. Y.; Xue, Y. J.; Ma, M.; Wang, S. Z.; Liu, N.; Chen, Y. J. ChemBioChem 2013, 14, 1544.

[23] Kennedy, J. Nat. Prod. Rep. 2008, 25, 25.

[24] Zhang, E.; Guo, H.; Chen, D. D.; Yang, Q.; Fan, Y. F.; Yin, Y.; Wang, W. G.; Chen, D. J.; Wang, S. F.; Liu, W. Org. Biomol. Chem. 2020, 18, 4051.

[25] Bratsch, S. G. J. Chem. Educ. 1985, 62, 101.

[26] Gan, T.; Liu, R.; Yu, P.; Zhao, S.; James M, C. J. Org. Chem. 1997, 62, 9298.

[27] Arai, M.; Yamazaki, T.; Tamaki, K. WO 113499, 2005.

[28] Jane, C. E.; Stacy, G. L.; Bryan, M. N.; Shi, Q.; Wang, M.; Alan M, W.; Xu, Y. WO 054176, 2005.

[29] Cai, Q.; Li, Z. Q.; Wei, J. J.; Ha, C. Y.; Pei, D. Q.; Ding, K. Chem. Commun. 2009, 7581

[30] Piscitelli, F.; Ligresti, A.; Regina, G. L.; Coluccia, A.; Morera, L.; Allara, M.; Novellino, E.; Marzo, V. D.; Silvestri, R. J. Med. Chem. 2012, 55, 5627.

[31] Kim, Y. A.; Han, S. Y. Synth. Commun. 2004, 34, 2931. 